\title{
GENDER IN THE MILITARY: ANDROCENTRISM AND INSTITUTIONAL REFORM
}

\author{
KATHRYN ABRAMS*
}

I

INTRODUCTION

During the past "Year of the Woman," feminists and their allies subjected a range of institutions to searching, well-publicized scrutiny. Women confronted practices of sexual harassment, challenged their underrepresentation in institutions, and questioned the double standards that have been applied to their work. Even the military, often insulated from the tides of public opinion, has not been immune from this scrutiny. Revelations of the Tailhook scandal, ${ }^{1}$ and of the ensuing cover-up, have brought pressure to bear on an institution slow to acknowledge its legacy of harassment. Military exclusion policies, which for many years met with quiescence or approval, have been challenged by straight women, gays, and lesbians. An institution conceived by many as the symbol of and training ground for traditional notions of masculinity ${ }^{2}$ has been forced to confront a range of issues implicating gender.

The fact that the challenge has been raised, however, marks only a beginning. Numerous questions remain about the arguments and the institutional mechanisms through which change can best be achieved. Part II of this article discusses the strategy that advocates should pursue in altering restrictive policies implicating gender. I argue that feminists and other proponents of change should not limit themselves to problem-specific analyses, but should attempt to elaborate and expose the androcentrism that thwarts systematic change in military institutions. This goal requires feminist advocates to undertake several tasks.

\footnotetext{
Copyright $(1993$ by Law and Contemporary Problems

* Professor of Law, Cornell Law School; Associate Professor, Program in Ethics \& Public Life, Cornell University.

I would like to thank Mary Katzenstein and Neal Devins for their thoughtful comments on an earlier draft, and Michelle Benecke (Military Officer 1983-1989) for superb research assistance.

1. This term refers to events at the 1991 Annual Tailhook Association Convention in Las Vegas, Nevada. The evenings at this convention were consumed by large, raucous, alcohol-infused parties, at which numerous women were fondled, sexually assaulted or compelled to pass through a "gauntlet" of probing hands. Senior Navy personnel who were present at, or in the hotel building during, these parties did nothing to stop the harassment.

2. This formulation and its relation to military exclusion policies is developed most thoughtfully and eloquently by Kenneth Karst. Kenneth Karst, The Pursuit of Manhood and the Desegregation of the Armed Forces, 38 UCLA L. REV. 499 (1991). Although I differ somewhat from Professor Karst in what I see as the comparative roles of the elected branches and the judiciary in bringing about change in this area, I have learned a great deal from his insightful, humane work.
} 
They must, first, expose the way in which those in positions of power make their own perspectives normative, both as to the means of achieving military goals and as to the characterization of nondominant groups, such as straight women, gays, and lesbians. They must, second, trace this theme through a variety of military policies and official responses to change. They must, finally, meet the official images of nondominant groups with an array of images generated by group members themselves and, in particular, resist the urge to describe groups by reference to a singular, "good soldier" characterization. Part III considers the institutional implications of this position, arguing that both courts and electoral institutions possess certain advantages in combatting androcentrism. In the end, the best solution may lie in institutional collaborations among the popular and judicial branches-and the people-in order to promote new understandings of gender and produce changes in gender-related policies.

\section{II}

\section{EXPOSING ANDROCENTRISM AS A STRATEGY FOR CHANGE}

Many military policies implicate questions of gender. Those which come most readily to mind include the exclusion of women from combat roles, and policies and practices related to sexual assault and harassment. ${ }^{3}$ Also included might be the military's exclusion of gays and lesbians, as this policy not only affects the eligibility of thousands of women but helps to create the military's image of what it means to be a man or a woman. ${ }^{4}$ Policies that relate to the work/family conflict, such as those establishing the terms on which pregnant women or mothers may serve, ${ }^{5}$ might also be placed within this category. With what kinds of arguments these policies should be examined or challenged remains an important issue, both at conceptual and strategic levels.

3. Women's combat restrictions are imposed by statute in the case of the Navy and the Air Force. See Act of Aug. 10, 1956, ch. 1041, 70A Stat. 528 (repealed 1991) (prohibiting the assignment of women in the Air Force "to duty in aircraft engaged in combat missions"); 10 U.S.C. § 6015 (Supp. III 1991) (prohibiting the assignment of Navy women "to duty on vessels or aircraft that engage in combat missions"). The other services have no statutory restrictions eliminating women from combat, although the Army in 1977 adopted a Combat Exclusion Policy, which prevents women from serving in certain jobs designated as "combat" military occupational specialties, and the Marine Corps, which comes under the command of the Navy Department, is subject to the restriction on women in 10 U.S.C. \& 6015 . See generally M.C. DEVILBISS, WOMEN AND MILITARY SERVICE: A HISTORY, ANALYSIS AND OVERVIEW OF KEY ISSUES 25 (1990).

4. This policy is not prescribed by an act of Congress, but by Defense Department regulation. This policy states in part: "Homosexuality is incompatible with military service. The presence in the military environment of persons who engage in homosexual conduct or who, by their statements, demonstrate a propensity to engage in homosexual conduct, seriously impairs the accomplishment of the military mission." Enlisted Administrative Separations, 32 C.F.R. pt. 41, app. A, pt. 1(H)(1)(a) (1992).

5. Exec. Order No. 10,240, 3 C.F.R. 749 (1949-1953), reprinted in 10 U.S.C.A. $\$ 3818$ note (West 1959) (requiring the mandatory separation of military women who became pregnant or became the parent of a natural, adopted or stepchild under a certain age). During the early 1970 s, several services mitigated the harshness of this rule by granting waivers to some pregnant women or mothers. In 1974, the Department of Defense told the services that they should develop policies making separation for pregnancy and motherhood voluntary rather than mandatory. See JUDITH STIEHM, ARMS AND THE ENLISTED WOMAN 117 (1989). 


\section{A. The Problem-Specific Focus}

In the past, feminists and other advocates of gender equality have approached change primarily in a problem-specific manner. They have opposed the gay/lesbian exclusion or challenged the adequacy of policies relating to sexual harassment, for example, rather than seeking connections among problem areas, or between problem areas and more pervasive characteristics of military institutions. This problem-specific emphasis made sense in several respects. First, some advocates may not have seen connections among different policies, or they may have believed that the differences between work/family policies, for example, and gay/lesbian exclusion were more significant than the similarities. Second, advocates may have perceived strategic reasons for persisting in singleproblem efforts. Broader-based challenges might require coalitions they were reluctant to forge, ${ }^{6}$ or threaten progress that appeared possible in narrower areas. Most importantly, problem-specific approaches seemed most likely to be palatable to the military leaders who were the targets of advocacy. These leaders perceive their institution to be a superb problem solver: abundant analytic and implementational resources, rigid hierarchical structure, and strict discipline all make the military an excellent forum for devising and implementing solutions to particular problems, including those involving group-based inequalities.

Military leaders have also responded with anger, but little comprehension, to systematic challenges to the nature or "culture" of their institutions. A good example is the recent furor over Carol Burke's article Dames at Sea. ${ }^{8}$ Burke, a former instructor at the Naval Academy, reflected on the connections between the Tailhook scandal and the misogynistic marching chants, rituals, and jokes in which midshipmen engage on a more routine basis. ${ }^{9}$ She concluded that "[w]hat happened at the Tailhook reunion was both traditional and criminal. Although a thorough criminal investigation may identify the perpetrators ... the deep-

6. Homophobic tendencies in the mainstream feminist movement, for example, may have made straight feminists, protesting the women's combat exclusion, reluctant to join forces with gays and lesbians protesting their exclusion from the services.

7. See e.g., Charles Moskos, How Do They Do It?, The New RepubliC, Aug. 5, 1991, at 16.

8. Carol Burke, Dames at Sea, The New RePublic, Aug. 17 \& 24, 1992, at 16.

9. Although these chants and jokes may be routine, from Burke's description they appear to be far from benign. Consider a variation on the traditional song "The Prettiest Girl":

The ugliest girl I ever did see

was beating her face against a tree

I picked her up; I punched her twice;

She said, "Oh Middy, you're much too nice."

Or two verses from the chant "My Girl Is a Vegetable":

My Girl ain't got no eyes

Just two sockets full o' flies. ...

Sometimes I even play a joke

Pull the plugs and watch her choke.

Burke, supra note 8, at 18. 
rooted misogynistic traditions that breed such behavior will be harder to uproot."10 Burke's article was greeted with a storm of criticism from Naval Academy officials. Some accused her of disloyalty in airing the Academy's dirty linen in public; others challenged the veracity of her account, arguing that because newly-minted rules proscribed such behavior, it could not have occurred; most claimed to find her account of a misogynistic "culture" unrecognizable and unhelpful as a prescription for change. ${ }^{11}$

Yet complicated and controversial as it may be, an approach which links a range of problems to each other, and to their roots in an androcentric military culture may be necessary to produce progress. Recent evidence suggests that, despite their apparent advantages, problem-specific approaches have backfired in troubling - though ultimately not surprising-ways. Two examples help to illustrate this difficulty.

The first comes from the area of sexual harassment. The pervasive sexual harassment discovered on the USS Safeguard produced massive Department of Defense and Navy studies, and resulted in the adoption of a "no tolerance" policy toward sexual harassment. ${ }^{12}$ Yet no sooner was this policy in place than the Tailhook scandal erupted. Not only was the investigation of that scandal thwarted by official hostility and frank attempts to protect responsible colleagues, the commander of the Naval Investigative Service responded by comparing female aviators to "go-go dancers, topless dancers or hookers." when women's advocates attempted to make the point that the women's combat exclusion helped to perpetuate second class citizenship of which harassment was another part, ${ }^{14}$ most military leaders voiced a complete inability to comprehend a connection. These developments underscore the very point made by Burke, that even a "no tolerance" policy is not going to produce satisfactory results if

10. Id. at 20 .

11. Interview with Associate Dean Carol Burke, Dec. 6, 1993 (notes on file with author). See also Correspondence, THE NEW REPUBLIC, Sept. 21, 1992, at 4-5 (letter from Admiral T.C. Lynch, Superintendent of the Naval Academy calling Dames at Sea "an inaccurate portrayal of today's environment at the [Academy]," in light of changes in official rules, including a "zero tolerance program for any gender discrimination or harassment"; reply from Carol Burke detailing sexist practices that continued after official policies were implemented). A less decorous response may be found in a letter to the President of Johns Hopkins University, the institution for which Burke left the Naval Academy, from John Sheehan, Vice Chairman of the Board of Trustees of the Naval Academy's Alumni Association. In a clear effort to discredit Burke with her new employer ("were I president of one of the nation's great universities, and had I a dean on my staff who would stoop to such filth-liberated woman though she may be-I would want to be informed about that"), Sheehan states "[w]hat Ms. Burke has written is so bizarre and so far beyond anyone's comprehension of what goes on at the Naval Academy that none of us can understand her motivation." In a revealing aside, Sheehan suggests that the article may have been published to vindicate the prejudice of New Republic Editor Andrew Sullivan-"an avowed homosexual"-against the military. Letter of John Sheehan to William Richardson, President of Johns Hopkins University, Aug. 28, 1992 (on file with author).

12. Ron Martz, Military is Beginning to Change Attitudes, ATLANTA Const., Oct. 5, 1992, at C4 (all four service chiefs have adopted "no tolerance" policy on sexual harassment); Editorial, Navy at Its Brassiest, N.Y. TIMES, Oct. 1, 1992, at A24 (citing adoption of "no tolerance" policy by Navy in 1990).

13. Eric Schmitt, Senior Navy Officers Suppressed Sex Investigation, Pentagon Says, N.Y. TIMES, Sept. 25, 1992, at A1.

14. Id. 
those responsible for enforcing it have not come to recognize the ways in which systematic devaluation of women pervades their attitudes and institutions.

The second example concerns the area of gay and lesbian exclusion. In January 1993, President Clinton moved, through a proposed executive order, to end the ban on gays and lesbians in the military services. ${ }^{15}$ Following vocal opposition by the Joint Chiefs of Staff ${ }^{16}$ and a threatened congressional rebellion spearheaded by Senator Sam Nunn, ${ }^{17}$ Clinton delayed imposition of the executive order for six months, in order to study approaches to implementation. ${ }^{18}$ Within days, reports surfaced that among the alternatives for implementation being considered were a ban on gays and lesbians in combat, and the establishment of segregated barracks and showers, in order to "respect the privacy of heterosexuals."19 There was, on the other hand, no consideration of whether the end of gay and lesbian exclusion should be accompanied by some revision in the uniform military code outlawing sodomy. Indeed, under the new policy, which restricts military inquiry and investigation, homosexual conduct-as well as acts such as hand-holding, which demonstrate "a propensity or intent to engage in homosexual acts"-remain a basis for separation, and "credible information of homosexual acts" provides grounds for investigation. ${ }^{20}$ These developments suggest that the modification of the ban will be accompanied by the continuing stigmatization of gays and lesbians, rather than by reexamination of the complex set of attitudes that produced it.

These difficulties have arisen because partisans on both sides have become accustomed to seeing specific gender policies in isolation. Had advocacy on the gay and lesbian exclusion been more consistently joined with advocacy on the (straight) women's combat exclusion, it might not have been so easy for Clinton Administration officials to contemplate going from a complete ban on gays and lesbians to a combat ban. Had women's advocates more systematically

15. Eric Schmitt, Clinton Set to End Ban on Gay Troops, N.Y. TiMES, Jan. 21, 1993, at A1.

16. Eric Schmitt, Joint Chiefs Fighting Clinton Plan to Allow Homosexuals in Military, N.Y. TIMES, Jan. 23, 1993, at A1.

17. Adam Clymer, Lawmakers Revolt On Lifting Gay Ban in Military Service, N.Y. TimES, Jan. 27, 1993, at A1; Michael Wines, This Time, Nunn Tests a Democrat, N.Y. Times, Jan. 30, 1993, at A1.

18. Gwen Ifill, Clinton Accepts Delay in Lifting Military Gay Ban, N.Y. TIMES, Jan. 30, 1993, at A1.

19. Eric Schmitt, Pentagon Aides to Study Option of Segregation for Gay Soldiers, N.Y. Times, Jan. 31, 1993, at A1. In his first official press conference, President Clinton surprised many observers by expressing his willingness to consider segregation of gay and lesbian soldiers, should the forthcoming Pentagon report recommend it. See Richard L. Berke, Clinton Says He'd Consider Separating Gay Troops: Remarks Are Contrasted With Earlier Stand on the Military, N.Y. TIMES, Mar. 24, 1993, at A1.

20. See Text of Pentagon's New Policy Guidelines on Homosexuals in the Military, July 20, 1993, at A16. See also Sam Verhovek, Gay Groups Denounce the Pentagon's New Policy, N.Y. TIMES, July 21,1993 , at A14. The implementation of this policy was suspended in the wake of a federal district court decision enjoining any action by the military that affects the enlistment status of, or results in the creating or maintaining of records on, gay and lesbian service members in the absence of proven sexual conduct-" if such conduct is proven to interfere with the military mission of the armed forces." Meinhold v. Department of Defense, CV 92-6044 TJH, Amended Order and Judgment, September 30, 1993 [unpublished order on file with author]. However, last month, the Supreme Court prepared the way for the implementation of the policy, by staying the court's order, on the ground that the district court could only order Meinhold's reinstatement. See Linda Campbell, Clinton Gay Policy Gets Legal Alert, Court imperils "don't ask, don't tell "standard, ChICAGo TrIBUNE, Nov. 17, 1993 at 1. 
connected a range of women's issues, military officials might not have been so perplexed by the claim that the combat exclusion bestows a kind of second class citizenship that facilitates or legitimates sexual harassment. But the problem with single-issue strategies goes beyond the failure to juxtapose related policies or issues. It lies in the failure to offer the kinds of explanations that juxtaposing and comparing policies makes possible.

Recent efforts at reform have treated discrimination in the military as if it arises from a simple cognitive error or category mistake: military personnel do not understand that harassing women is unacceptable or that gays and lesbians can function as soldiers. All that is necessary is to correct these errors-by imposing a "no tolerance" policy, for example-and the problem will disappear. The foregoing problems indicate that this is not the case. I would argue instead that discriminatory behavior and policies should be described as arising from a complex intersection of attitudes and structures built on those attitudes that I will describe as androcentrism. Specific policies must be treated within a painstaking elaboration of this larger problem before effective reforms can be devised.

\section{B. Androcentrism in the Military}

Androcentrism, a term which traces its origins back to Charlotte Perkins Gilman in the early twentieth century, ${ }^{21}$ has several components. Androcentrism is based on the premise that the structure of the society or institution in question is "patriarchal": that is, that all of the relevant positions of power are held by men. ${ }^{22}$ Yet, as feminist theorist Sandra Bem points out, the more important meaning of androcentrism lies in three additional premises. First, those men who hold the positions of power describe the world through their own eyes, yet think that they have described the world as it exists in some universal, objective sense. ${ }^{23}$ Second, these men define other people in relation to themselves as either being the same or being different. ${ }^{24}$ Third, those who are classified as different are "otherized"-that is, characterized as being as alien and non-normative as possible - and their value or function is depicted only in relation to the dominant group, rather than as they themselves might see it. ${ }^{25}$ Explanations emphasizing androcentrism thus focus not on the characteristics of the group suffering discrimination-be it straight women, gay men, or lesbians-but on the power held by the dominant group and the way it permits them to shape determinative understandings of the world, and the nature and role of others.

21. See Charlotte Perkins Gilman, The Man Made World or Our Androcentric Culture (1911), cited in SANDRA BEM, THE Lenses of Gender: Transforming THE DeBATE ON SEXUAL INEQUALITY 41 (1993).

22. See BEM, supra note 21 , at 40.

23. Id. at 42 .

24. Id.

25. Id. 
Androcentrism has been a critical explanatory concept in addressing gender discrimination in civilian workplaces. Efforts to end women's exclusion from professional and blue-collar jobs began not by examining the source and evolution of workplace norms, but by accepting them at face value. Women argued that they should be granted access to jobs because they could perform them the same way as men. ${ }^{26}$ This argument prevailed in many battles for access, but it turned out to be an incomplete solution. ${ }^{27}$ When women entered the workplace, they discovered that performing these jobs the same way as men meant performing them on a full-time, consistent basis throughout their careers, without accommodation of their (starkly different) responsibilities for home and family. ${ }^{28}$ It also meant performing these jobs in environments where they were subject to both subtle and blatant derogation and to sexual harassment ranging from verbal epithets to sexual assault. ${ }^{29}$ And it meant discovering that the characteristics of good performance according to which their work was judged-be it firefighting or lawyering-were oddly coterminous with male physical capacity or socialization.

These difficulties were not effectively combatted by the arguments that had won women access. In relation to the work/family conflict and male standards of job performance, these arguments only exacerbated women's difficulties by exposing them to arguments that they "wanted it both ways" in the workplace. ${ }^{30}$ Arguments that women could work the same way as men did little to explain why they were hindered and offended by sexualized conduct-much of which had long been part of predominantly male workplaces. It was only as women stopped emphasizing their ability to conform to pre-existing standards and started challenging the origins and partiality of these standards that they gained the flexibility necessary to address a number of different problems in a consistent and mutually reinforcing fashion.

The newer arguments stressed that by virtue of ongoing male control of most workplaces, the norms that structured the workplace were developed by and for men. ${ }^{31}$ The male biography defined the proper extent of commitment to a job;

26. See Kathryn Abrams, Roving Biologism, Social Construction and Reasonable Women: A Response to Professor Epstein, 41 DEPAUL L. REV. 1021 (1993) [hereinafter Abrams, Roving Biologism]; Kathryn Abrams, Gender Discrimination and the Transformation of Workplace Norms, 42 VAND. L. REV. 1183 (1989) [hereinafter Abrams, Gender Discrimination].

27. The same can be said of the second strategy employed by women in the workplace: arguing that they worked differently from men. See Abrams, Roving Biologism, supra note 26; Joan Williams, Deconstructing Gender, 87 MICH. L. REV. 797 (1989).

28. See Abrams, Gender Discrimination, supra note 26; Nancy E. Dowd, Work and Family: The Gender Paradox and the Limitations of Discrimination Analysis in Restructuring the Workplace, 24 HARV. C.R.-C.L. L. REV. 79 (1989); Mary Joe Frug, Securing Job Equality for Women: Labor Market Hostility to Working Mothers, 59 B.U. L. REV. 55 (1979); Williams, supra note 27.

29. See Catharine A. Mackinnon, The Sexual Harassment of Working Women: A Case OF SEX DisCRIMINATION (1979); Abrams, Gender Discrimination, supra note 26.

30. These claims structured the seemingly endless "equal treatment/special treatment" debate in the area of pregnancy benefits and family leave. See Lucinda M. Finley, Transcending Equality Theory: $A$ Way Out of the Maternity and the Workplace Debate, 86 CoLUM. L. REv. 1118 (1986); Herma Hill Kay, Equality and Difference: The Case of Pregnancy, 1 BERKELEY WOMEN's L.J. 1 (1985).

31. See Gender Discrimination, supra note 26. 
the male physiology or socialization established the qualities that conduced to good performance. ${ }^{32}$ The male need for entertainment, company, or conquest determined the degree of sexual conduct that was appropriate on the job. Until it was challenged by feminist advocates, this inevitable correspondence was not called male power or male perspectivity; it was simply called "work." Feminist advocates also pointed out that women were effectively characterized as "other" at work. Their persistent sexualization through propositions, epithets, and pornography constructed them as different from men, and deserving of devaluation. Insensitivity to the partiality of established standards led men to ascribe women's failures to meet them as defects in women, which also served to reinforce their differences. Whether by sexualizing women, holding them to partial standards, creating sex-segregated ghettos of female service workers, or characterizing them in relation to nonworkplace roles (such as mother, sister, wife) rather than by reference to their professional setting, men in the workplace thought about women in relation to themselves, rather than as beings in their own right. This critique has allowed women to explain more effectively why sexual harassment is a problem, or why it is wrong to insist on uninterrupted, full-time workplace participation or to judge women for being insufficiently aggressive. It has demanded of workplace managers that they ask who holds the power and whether they exercise it equitably in relation to an increasingly plural workforce.

A similar critique holds promise in the military area, for the military, like most civilian workplaces, displays many features of androcentrism. First, the military is undeniably patriarchal: virtually all positions of power are held by men-in this case it is significant to add-heterosexual men. ${ }^{33}$ Second, these men describe the world through their own eyes and purport to have described it in its essence. The perspectivity, or partiality, of their view is often difficult

32. A similar argument is made regarding the workplace and other contexts by Catharine MacKinnon. See CATHARINE A. MACKInNON, Difference and Dominance, in FEMINISM UNMODIFIED: DISCOURSES ON LIFE AND LAW 36 (1987) (“. . . their socially designed biographies define workplace expectations ... Their presence defines family, their inability to get along with each other ... defines history, their image defines god, and their genitals define sex."). These factors lead MacKinnon to conclude that "the structure and values of American society" constitute an "affirmative action plan" for men. Id. at 36. MacKinnon offers what might be described as a version of androcentrism. It assumes that men hold positions of power and operate as the measure of all things in our society, and it argues that men conceal the perspectivity of their world view in claims of universality or objectivity. But it describes what Bem calls the process of "other-izing" in a more particularized fashion. Women are not simply constructed as alien and devalued but, more specifically, as sexualized and subordinate. Men maintain their power not simply through the power of description (and related non-violent social powers of construction) but through acts of sexualized violence and aggression against women. Id. at 40-45.

33. It is also true that most positions of power are held by white heterosexual men. Charles Moskos reported that in the Army, for example, there are only 85,000 noncommissioned black officers, 7,000 black officers and 26 black generals (representing $6 \%$ of all generals), including of course Colin Powell, the former Chairman of the Joint Chiefs of Staff. Moskos, supra note 7, at 18,20. However, while the numbers remain small, there are not, as in the case of gay men, formal barriers to black access; on the contrary, the military has implemented programs deemed by some to be more effective than civilian efforts to integrate black soldiers and mitigate prejudice. See id. 
to identify, because divergences from the views of other observers are defended on the basis of expertise.

This latter pattern can be observed with respect to claims of combat effectiveness. Many exclusionary policies, such as the gay and lesbian ban or the (straight) women's combat ban, are justified on the ground that the presence of these groups in the combat arms would disrupt military discipline and make effective defense impossible. ${ }^{34}$ Competing claims by advocates of excluded groups are met with the argument that the experience of the Joint Chiefs, or the leaders of a particular service, enables them to be the best judges of what conduces to combat effectiveness. This claim is difficult to meet precisely because it is partly true. Military leaders do have more training and experience than anyone else in what conduces to combat effectiveness. But this training has also taken place in a particular setting, with particular colleagues, who share particular attitudinal assumptions. The insulation of this group within, and its virtually uncontested control over, military institutions has reinforced these homogeneous attitudes. It is often difficult to tell whether a particular conclusion about combat effectiveness is informed by technical knowledge of the requirements of combat, familiarity with or commitment to a way in which combat has traditionally been conducted, or both. ${ }^{35}$ Often it requires an exigent circumstance, which suspends dominant assumptions to determine whether it is the technical requirements of combat or the assumptions of those waging it that justify a particular exclusion.

One such circumstance was Truman's executive order requiring racial integration of the armed forces. Military leaders had argued fervently that integrating units would disrupt military discipline, and that white soldiers would refuse to serve under or take orders from black superiors. Yet when the order was issued, military leaders realized that they had to put their experience to work implementing rather than resisting integration. Although the resulting struggles continued for many years, ${ }^{36}$ including times when black soldiers responded angrily to both civilian racial strife and continuing discrimination in the military

34. See Schmitt, supra note 16, at A1; JEANNe Holm, Women IN THE Military: THE UNFINISHED REVOLUTION 341 (1982) (citing Retired Gen. Westmoreland as testifying that proposals to place women in combat show "utter disregard for potential fighting effectiveness . . . no man with gumption wants a woman to fight his battles").

35. An analogy to the civilian workplace might be useful here. Parents (most frequently mothers) seeking to mitigate work/family conflict have sometimes asked their employers to implement job-sharing. Many times employers respond with the argument that a particular job cannot be shared if a satisfactory product or service is to be rendered. Although the employer has significant experience with what conduces to a good performance of a particular job in his (her) workplace, most workplaces have been structured in a way that requires each job to be performed solely by a particular person. So while experience, in the sense of technical knowledge, may be one factor informing an employer's refusal to consider job-sharing, experience, in the sense of familiarity with or exposure to only one mode of operation, can be another. To overcome the latter barrier it has often been necessary to experiment with job sharing, or to study the experience of workplaces in which single-occupant job roles have not been assumed.

36. Moskos, supra note 7, at 16 . Some soldiers argue that these difficulties have yet to be fully resolved. Moskos quotes a number of black soldiers as contending that "[t]he whites are still top dog" in the armed forces, and "the brothers know it." Id. 
ranks, the military implemented a series of programs which have mitigated racial tensions and equalized opportunity to a degree rarely achieved in civilian society. ${ }^{37}$ During the armed combat in Desert Storm, for example, there were no racial incidents severe enough to be brought to the attention of military police. ${ }^{38}$

A more limited example comes from the Vietnam War. A traditional argument raised against women in ground combat is that they lack the size and upper body strength necessary to wage effective combat. ${ }^{39}$ Yet during the Vietnam War, the United States was compelled to arm and train a fighting force that possessed at least one of these drawbacks. The South Vietnamese troops were, on average, considerably smaller than the caucasian and black men that make up the majority of the U.S. fighting force. Because the nature of the conflict did not permit the United States to refuse to assist such troops, the military took another route: it took overseas a weapon, the $M-16$, that was smaller, lighter and could more effectively be used by troops the size of the average Vietnamese man. ${ }^{40}$ Once inclusion of troops with different physical characteristics became a priority, military technical knowledge was put to work to make accommodation possible.

Recognizing this aspect of androcentrism in the military does not mean rejecting, or even contesting, all claims of military expertise. It means acknowledging that expertise can mean not only greater technical knowledge, but more consistent exposure to shared attitudes or contextual limitations: for example, the expectation that one will and should share the exigencies of combat with other straight men. It requires a vigorous effort to identify these different threads in experience and to use technical knowledge where necessary to overcome attitudinal limitations.

The third feature of androcentrism present in the military is that those in power define everyone else in relation to themselves, as either the same or different: those who are different are characterized as being polar, alien, or

37. Id.

38. Id.

39. See Karst, supra note 2, at 523 (citing physical arguments in favor of combat exclusion); The Argument Against Female Combatants, in FEMALE SOLDIERS-COMBATANTS OR NONCOMBATANTS?: HiSTORICAL AND CONTEMPORARY PERSPECTIVES 247 (Nancy Goldman ed., 1982). Those who take a more positive view of women in combat are divided between those who are willing to acknowledge the relevance of strength differentials in some areas but emphasize the many areas in which they do not affect performance, see, e.g., HoLM, supra note 34, at 396, and those who emphasize the fact that the services' approaches to measuring and implementing policy relating to strength differentials are too inconsistent to permit conclusions as to their relevance, see, e.g., STIEHM, supra note 5, at 198-205.

40. See Karst, supra note 2, at 532. Karst also notes that the M-16 was used by Captain Linda Bray in her now-famous exchange of fire in Panama. Id. That a similar effort to supplement size and strength with technology - permitting women into combat as fighter pilots or on combat ships-has generated significant controversy suggests that it may be expectations, as much as expertise, that ground the reluctance in this case. See PRESIDENTIAL COMMISSION ON THE ASSIGNMENT OF WOMEN IN THE ARMED FORCES, MEMORANDUM: APPROVED RECOMMENDATIONS 5 (1992) [hereinafter PRESIDENTIAL COMMISSION] (stating that law and policies should be modified to permit women to serve on combat vessels; but laws and policies prohibiting women from assignment to duty on aircraft engaged in combat missions should be retained, codified or re-enacted). 
without value. This is true not only of the way that the military characterizes enemies in wartime, but of the way heterosexual males in the armed forces characterize others within their ranks. Kenneth Karst has offered a cogent explanation of the psychological function served by this devaluation of straight women, gays, and lesbians: it reasserts the value of, and associates the dominant group more strongly with, the elusive, highly-charged, anxiety-producing traditional norm of masculinity. ${ }^{41}$ I am less concerned with the motive, however, than with the regularity with which such distancing and devaluation occur, and the mechanisms through which they are effected. Military cadence calls, jokes, and rituals that describe women as ugly, overweight, unsanitary, or masochistic serve this function, ${ }^{42}$ as do sexual assault and sexual harassment of enlisted women. The recent depiction of "overt homosexuals" as perpetually cruising predators who will treat straight soldiers as sexual objects provides another example. ${ }^{43}$ Exclusion policies, such as the gay and lesbian exclusion and the (straight) women's combat exclusion, accomplish a similar purpose in a subtler way. Although such exclusions do not, on their face, stigmatize straight women, lesbians, or gay men, they set them apart from straight male soldiers, and the justifications that are offered in their defense may be more overtly stigmatizing.

Finally, military leaders view groups which are "other" according to the function they serve in, or the effect that they have on, the lives of the dominant group. They do not view excluded groups as beings in their own right; that is, the groups' own perspectives, or views of themselves, are not taken into account. When the Clinton Administration proposed ending the gay and lesbian ban, the question was the effect that gay soldiers' (uncloseted) presence would produce on the dominant group: this was the reason for the pervasive concern with the "privacy of heterosexual soldiers." At no point did military leaders view the matter from the perspective of gays and lesbians, asking how it would feel to be excluded, segregated, or restricted from combat, or how it would feel to be included under circumstances where some preferred forms of sexual contact-far from being celebrated in the fashion of heterosexual soldiers-were designated a violation of military law.

41. See Karst, supra note 2, at 506-07.

42. See Burke, supra note 8 , at 18 .

43. The emergence of and emphasis on the term "overt homosexual"-with the derogatory, highly sexualized images it connotes-has been an interesting feature of the current debate over the gay and lesbian exclusion. The term appears to have emerged in response to the (accurate) claim that there are, at present, thousands of closeted gays and lesbians serving in the armed forces. It reflects an understanding, sometimes made explicit by military leaders, that if gays and lesbians are required to hide their sexual orientation, their divergent sexuality will not disrupt military discipline; but, if they are permitted to come out to other soldiers, their sexualized, predatory culture will envelop the military. As former National Public Radio correspondent Frank Browning-a gay man-has observed, this depiction represents an interesting reversal of the stereotypic characterization of gays and straights: "we're the tigers and they're the poofs." Fresh Air, Interview with Frank Browning (March 10, 1993). This understanding, of course, rests on equally stereotyped images of gays and lesbians, which I argue are both contested and abetted by the "good soldier" approach taken by opponents of the exclusion. See infra text accompanying notes 46-51. 


\section{Exposing Androcentrism: Elements of Strategy}

What sort of strategy is implied by the recognition that androcentrism lies at the heart of numerous gender-specific policies? Several elements are particularly important. The first is to offer detailed accounts of the partiality and perpetuation of dominant, straight male perspectives, as I have attempted above. Androcentrism relies, in a paradoxical way, on the invisibility of these perspectives: when they are taken not as a point of view, but as "military life," androcentrism is particularly secure. Explaining the mechanisms for the generation and perpetuation of these perspectives makes them seem less universal and inevitable; it makes them more vulnerable to challenge by those who can advance alternative views.

Detailed explanations of the elements and devices of androcentrism may also be useful in educating resistant military leaders. References to military "culture" may be vague enough to make even well-meaning officials throw up their hands; but elaboration of the particular means through which specific attitudes and characterizations become shared truths may be more effective. Of course, an immediate positive response is hardly to be expected; the reception of Carol Burke's admirably concrete attempt to connect seemingly inconsequential habits and customs with larger patterns of gender oppression is a chastening example. But the more fully and more frequently military leaders are confronted with accounts of these dynamics, the more familiar they will become.

This last point previews the second element of a strategy associated with the exposure of institutional androcentrism. More general discussion of androcentrism must be used to explain both specific policies and the military response to change. For example, the androcentrism critique explains the inadequacy of military response to the single-problem areas described earlier. It should be no surprise, in light of this critique, that the adoption of a "no tolerance" policy in regard to sexual harassment has not solved the problem. The policy conflicts with a range of other messages military personnel receive that women are pejoratively, debilitatingly different and do not belong. Until military leaders begin to realize how pervasive such derogatory attitudes are and how many hindering official and unofficial forms they can take, it will be difficult to address the problem more fully.

Similarly, androcentrism makes it possible to explain how alternatives like segregation and combat exclusion have followed attempts to end the ban on gays and lesbians. Gays and lesbians are not only effectively "other-ized" within the military; they are considered primarily by reference to their impact on the lives of heterosexual males. So it is not surprising that the first questions raised by their integration were how to protect the "privacy" of straight men and how to preserve combat effectiveness in a force that leaders had always (if not always correctly) conceived of as consisting exclusively of straight male soldiers. If the gay and lesbian ban is not to be succeeded by other similarly stigmatizing measures, military leaders must learn to consider questions of inclusion from the perspectives of nondominant groups as well. 
A final strategic consideration concerns the generation of oppositional images. Part of the strength of androcentrism lies in its power to characterize nondominant groups in ways that facilitate their continued subordination. These images, like the understandings of what conduces to military discipline, are often taken not as perspectives but as facts. Generating opposing images of these groups can be important not only in making visible the partiality of these perspectives but in supplying alternatives that might inform military decisionmaking.

One critical question concerns the kind of oppositional images that should be generated. Over the past few years, the predominant model for characterizing members of the affected group(s) has been the "good soldier." Straight women, gays, and lesbians who are subject to exclusion from one or more facets of military service have been characterized as highly competent members of the armed forces, who discharge their present duties with skill and commitment, and are capable of enhanced responsibilities. Women have the capacity to conceive children, but their childbearing is likely to be postponed and their fertility kept under "military" discipline. Gays and lesbians perform their duties with distinction and without making anyone aware of their sexual orientation.

In some respects, this "good soldier" characterization seems to be a reasonable strategy. Many of those targeted by the policies discussed here are in fact good soldiers, whose difference in gender or sexual orientation has little, if any, impact on their performance. ${ }^{44}$ More importantly, the appeal to the dominant norms of the challenged institution-like civilian feminists' invocation of women's similarities to men-has seemed to be a strategically safe approach. By characterizing stigmatized groups according to the military's own criteria, advocates would seem to minimize the number of contested issues and maximize their chance of persuading military leaders.

Yet as feminist experience with civilian workplaces suggests, this "safe" strategy does not always produce the desired change, and often entails problematic consequences. In particular, the "good soldier" approach-like the "sameness" approach to the civilian workplace that preceded it-undermines the broader effort at gender equality by accepting two central premises of the androcentric world view. First, it accepts the view of professional standards promulgated by the dominant group without challenging its premises, origins, or perspectivity. And second, it accepts the androcentric practice of measuring

44. Some, such as the gay and lesbian soldiers who have recently challenged the exclusion policy in court and in the media, are exemplary members of the service, whose loss has been or would be deeply felt by those with whom they work. See Watkins v. United States Army, 847 F.2d 1329 (9th Cir. 1988), aff'd on other grounds, 875 F.2d 699 (9th Cir. 1989) (en banc), cert. denied, 498 U.S. 957 (1990); Ben-Shalom v. Marsh, 881 F.2d 454 (7th Cir. 1989), cert. denied, 494 U.S. 1004 (1990).

In addition, social and technological changes have in fact mitigated some of the factors that impeded women in their efforts to become good soldiers. Contraception has made it possible for women to control their fertility; the advent and growing social acceptance of organized childcare has made it at least theoretically possible for women with children to pursue ambitious and time-consuming careers. See Michelle Benecke, Beyond Fighter Pilots: Exploding the Military's Combat Exclusion Policy (unpublished manuscript, on file with the author). 
others by the standard of the dominant group and finding them either (collectively) similar or (collectively) different.

As we saw above, a critical component of androcentrism is the power to present dominant understandings as inherent in the nature of the institutions, rather than as connected to the identity or experience of those who hold power within them. As women have discovered in civilian workplaces, accepting dominant (male) definitions of job performance perpetuates this power in several ways. First, it tends to depict job performance requirements as static, rather than subject to ongoing revision, even within androcentric institutions. The "good soldier" calls up legitimating images of hand-to-hand ground combat and fighter pilots dodging anti-aircraft fire, but it relinquishes the opportunity to emphasize the increasing pluralism of "soldierly" roles-that is, one can also be a good soldier by aiming scud missiles, miles away from the intended target-some of which may operate to the advantage of nondominant groups like women. ${ }^{45}$

Adopting the dominant standards of job performance foregoes the important opportunity to disentangle the demands of the institutional setting from the perspectives of those currently exercising power within it. If feminists in professional civilian workplaces had continued to take established performance criteria as given, they would never have been able to challenge attributes ranging from a "commanding" manner to uninterrupted career emphasis to singleoccupant jobs as functions of the male biography rather than of the work at hand. ${ }^{46}$ These kinds of understandings will be critical in the military context as well, as nondominant groups begin the task of separating the requirements of combat from the expectations and assumptions of those heterosexual males who have historically comprised the fighting force.

Moreover, uncritical acceptance of the dominant standards of performance sends a problematic message about who should bear the burden of accommodation as women enter a new workforce. Embracing existing standards suggests that women should conform their conduct to existing rules. By failing to make the point that institutions do and should change as they adapt to increasingly pluralistic constituencies, nondominant groups perpetuate the myth that current leaders have captured the essence of the job in question, and cede moral high ground that they could use in making demands for institutional change. ${ }^{47}$

45. See Michelle Benecke, supra note 44, at 5-8 (explaining that women may actually have advantages in certain kinds of combat, which are obscured when their qualifications are determined by reference to a male standard).

46. Acceptance of dominant standards for performance can also foster an elitism which produces unnecessary and injurious distinctions among members of the excluded group. In professional workplaces, for example, "male" characteristics including credentials and personal manner did not turn out to be equally distributed among or accessible to all contending women. The ability to compile a resume which resembled that of a man's tended to be correlated with race and socioeconomic privilege. The ability to develop a personal manner that avoided the twin evils of departing too much from the male model and simulating it so precisely as to induce anxiety in male evaluators tended to be found among more privileged women as well. See generally MACKINNON, supra note 32, at 70-77.

47. They also leave themselves without recourse if and when it becomes obvious that certain previously excluded groups cannot completely conform to dominant standards framed without the new 
The "good soldier" characterization also fuels the androcentric notion that all groups are unitary in nature and should be described as either similar to or different from the dominant group. Perpetuating the dominant group as a point of reference is one problem: what is needed is to present nondominant groups through their own eyes, as subjects in their own right, rather than in relation. But to invoke unity, on the one hand, and similarity, on the other, creates further difficulties. Asserting similarity may be a losing battle in a setting where the dominant group is committed to constructing difference and has many resources at hand through which to do so. Feminists have also learned through hard experience the dangers of engaging in unitary representations.

Predictably, the view which is universalized reflects the lives or circumstances of more privileged women, ${ }^{48}$ and the marginalization of the less privileged replicates within the group the logic and hierarchy of androcentric institutions. ${ }^{49}$ The monolithic image of the "good soldier," whose sexual orientation plays no role in his or her interaction with fellow soldiers, could marginalize those who, like some straight soldiers, wish to be more forthcoming about the details of their personal lives. ${ }^{50}$ The "good soldier" image might also submerge within military

entrants in mind. In her article "Beyond Fighter Pilots," Michelle Benecke argues that by emphasizing the highly successful (and largely conforming) performance of female pilots in the Gulf War, women's combat advocates have failed to shed adequate light on the ways in which women soldiers do not and cannot conform to a male model, with the consequences that the military has not only failed to accommodate such factors as pregnancy and childrearing, but has offered them as reasons for excluding women from combat. See Benecke, supra note 47, at 5-8. Benecke argues, however, that it is not women's experience or characteristics but the military's institutional arrangements that make women's perceived differences seem problematic for combat readiness. Benecke argues that the military should replace the standard of male performance with "job-validated requirements for each specialty;" accommodate pregnancy in the same manner as other "workaround" situations; and treat child care as a family issue rather than a women's issue. Id.

48. See generally Elizabeth V. SPELman, Inessential Woman: Problems of Exclusion in FEMINIST THOUGHT (1988); Patricia A. Cain, Feminist Jurisprudence: Grounding the Theories, 2 BERKELEY WOMEN's L.J. 191 (1988); Angela P. Harris, Race and Essentialism in Feminist Legal Thought, 42 STAN. L. REV. 581 (1990).

49. See Martha Minow, Feminist Reason: Getting It and Losing It, 38 J. LeGAL EdUC. 47 (1988). In the $60 \mathrm{~s}$ and $70 \mathrm{~s}$, when women were depicted as competent workers who sought the opportunity to perform the tasks that had been performed by men, women who remained at home to care for children felt that their lives had been marginalized and devalued by the dominant characterization. Kathryn Abrams, Ideology and Women's Choices, 24 GA. L. REV. 761, 778 (1990). When anti-rape advocates described women as victimized once by male aggression and once by the criminal justice system, black women argued that this characterization neglected to present the divergent circumstances of their lives: lives in which black women's rape had not until recently been criminalized, and in which the bias-laden "myth of the black rapist" made enhanced prosecution efforts perilous for their husbands, sons, and neighbors. See Kimberle Crenshaw, Whose Story Is It Anyway? Feminist and Antiracist Appropriations of Anita Hill, in RACE-ING JUSTICE, EN-GENDERING POWER (Toni Morrison ed., 1992); Dowd Hall, The Mind That Burns in Each Body: Women, Rape and Racial Violence, in THE POWERS OF DESIRE 328-49 (Ann Snitow et al. eds., 1983).

50. As Professor Anna Marie Smith has noted, through such images, a predominantly straight public "gets the pleasure of an incredibly straight gay representation." Anna Marie Smith, Comments at Women's Studies Colloquium, Cornell University (February 19, 1993).

Perhaps not surprisingly, this characterization may be applied to gay and lesbian soldiers who are, in fact, forthcoming or even flamboyant about their sexual orientation. The "good soldier" depiction of Perry Watkins in the various incarnations of the Watkins case contrasts sharply with his own selfdepiction in MARY ANN HUMPHREY, MY COUNTRY, MY RIGHT TO SERVE (1990), in which he describes 
reform efforts the range of feminists who are more disturbed by an institutional relationship between women and combat. ${ }^{51}$

Some unity in characterization may be necessary in order to put institutions on notice regarding the features they will be obliged to accommodate. But the rigidity and conformity of the "good soldier" model makes it of questionable value in challenging the androcentric military norms.

\section{III}

\section{INSTITUTIONAL CONSIDERATIONS}

During his first week in office, President Clinton proposed an executive order ending the ban on gays and lesbians in the military. That same week, a federal district court held for the first time that the exclusion policy violates Equal Protection. ${ }^{52}$ Less than a year later, the Clinton Administration, its initiative vitiated by a long struggle with the Senate and the Joint Chiefs of Staff, announced an anomalous compromise popularly known as "don't ask, don't tell." Implementation of the policy was temporarily blocked by a sweeping injunction issued by the same district court, which forbade any discrimination against gays and lesbians by U.S. military forces. ${ }^{53}$ This confluence of events frames nicely

himself as seeking out sexual encounters with other gay soldiers in a variety of settings, and of being paid by the military to entertain the troops in drag. Id. at 252-54.

However, under the impending “don't ask, don't tell, don't pursue" policy, gay and lesbian soldiers who are forthcoming in this way are subject to investigation regarding and separation for evidence of homosexual conduct, notwithstanding the fact that their military performance may be exemplary.

51. One factor which has slowed women's mobilization in opposition to the combat exclusion was the fact that women, and feminists, have varying views on the relationship between women and combat. Some, who describe themselves as "equality" feminists, believe that women should be permitted to fight, but that their entry into combat forces will not change the nature of or the decisions regarding armed exchange. See Holm, supra note 34, at 394-97. Others, who might be described as "difference" or "cultural" feminists, believe that women's distinctive modes of knowing and decisionmaking mean that their addition to combat forces will change models of military decisionmaking. See Paula Lee Potts, Do Women Belong in the Military? A Debate, MILITARY LIFESTYLE (Oct. 1989) at 46, 49 (citing M.C. Devilbiss, a former Army officer now a NCO in the Air National Guard: By being allowed into combat roles, women can demythologize the notion that the act of combat is heroic and glamorous. Combat should be a last resort . . . . Women warriors know this."); Sara Ruddick, Drafting Women: Pieces of a Puzzle, in CONSCRIPTS AND VolunTEERS 214, 229-38, (Robert K. Fullinwider ed., 1983) (arguing that women, being socialized to "maternal thinking" and consequently "more peaceful" than men, "might pacify the military and change the nature of battle"). Still others, who count themselves as "difference" or "radical" feminists, argue that women's distinctive perspectives-borne of divergent epistemology or the experience of male violence-should be used to keep the peace rather than to wage war; so that moving women into combat should be a lower priority than working to prevent combat altogether. See BELL HOOKS, FEMINIST THEORY: FROM MARGIN TO CENTER 117-31 (1984) (stating that women should resist the urge to characterize violence and militarism as inherently masculine, but as victims of violence should work-with men-to resist the use of violence as a form of social control); Ruddick, supra, at 231 (quoting Helen Caldicott as arguing that women in particular should do the work of peace because they "understand the genesis of life"); Ann Scales, Militarism, Male Dominance and Law: Feminist Jurisprudence as Oxymoron?, 12 HARV. WOMEN's L.J. 25 (1989) (arguing that women and lawyers should learn pacifism and responsibility for government action from the Greenham Commons Women's Peace Encampment).

52. Meinhold v. Department of Defense, 808 F. Supp. 1455 (C.D. Cal. 1993).

53. See Meinhold v. Department of Defense, CV 92-6044 TJH, Amended Order and Judgment, September 30, 1993 (unpublished order on file with author); Robert Reinhold, Los Angeles Portrait: $A$ 
a final strategic question. There are numerous institutional avenues for addressing military policies implicating gender, a fact which confronts advocates with difficult choices. When the goal is not only to end discriminatory policies, but to respond to such policies in ways that expose and combat institutional androcentrism, the choices become more complicated. Both courts and elected branch institutions have strengths and weaknesses in advancing this agenda, and the best results may be achieved through combination and interaction among them.

\section{A. The Quandaries of Adjudication}

For years it was assumed by gay and feminist advocates that changes in policies, particularly those involving exclusion, would come from the courts. Not only did the conservative tone of the Republican administrations and their powerful record of vetoing congressional initiatives give partisan reasons to doubt elected branch action but the political insulation of the courts, and their history of protecting disempowered groups against majoritarian oppression, ${ }^{54}$ were thought to create independent institutional advantages. In the first flush of the Clinton Administration, many of these conclusions were reversed: years of struggle over civil rights remedies and years of conservative appointments created greater ambivalence about the judiciary. Moreover, the energy and activism of the new President inclined many advocates toward an electoral branch solution. In fact, neither of these contrasting preferences has been fully borne out. While it is difficult to talk about institutional powers in abstraction from the question of who is exercising them, the courts have both strengths and weaknesses for implementing a critique of androcentrism in the military.

The drawbacks of the courts may be more apparent at first glance. Primary among them is a doctrinally entrenched posture of deference toward military policy. ${ }^{55}$ This deference reflects first a lack of institutional competence: judges

Judge Who Challenges the System, L.A. TIMES, Oct. 24, 1993, at 18 (describing Judge Terry Hatter, Jr.'s order, issued one day before the new policy was to go into effect on October 1). The Court of Appeals for the Ninth Circuit declined to stay the district court's order pending appeal, which will be heard in December. See Joan Biskupic, Administration Divided on Gays-Military Strategy; Pentagon Wants to Seek Emergency Stay of Ruling, WASH. POST, Oct. 22, 1993, at A2. The Supreme Court, however, was willing to stay the order, permitting the implementation of the policy. See Linda Campbell, Clinton Gay Policy Gets Legal Alert, supra note 20. Weeks later, however, the policy received another challenge, this time from a D.C. Court of Appeals opinion ordering the reinstatement of Joseph Steffan, who had been forced to resign from the Naval Academy after telling a superior he was homosexual. See John Lancaster \& Michael York, Court Reinstates Gay Midshipman, WASH. PoST, Nov. 17, 1993, at A1.

54. For a more skeptical view of the power of courts to produce social change on behalf of systematically disadvantaged groups, see GERALD N. ROSENBERG, THE Hollow Hope: CAN COURTS Bring About Social Change (1991).

55. The Seventh Circuit opinion in Ben-Shalom v. Marsh is illustrative:

[I]t is difficult to conceive of an area of governmental activity in which the courts have less competence. The complex, subtle, and professional decisions as to the composition, training, equipping, and control of a military force are essentially professional military judgments, subject always to civilian control of the Legislative and Executive Branches. The ultimate responsibility for these decisions is appropriately vested in branches of the government which are periodically subject to electoral accountability. It is this power of 
lack the information, or the processes for gathering it, that would facilitate technical judgments about the nation's defense. But the courts' deference also reflects a lack of institutional entitlement. The president and the Congress are authorized by the Constitution ${ }^{56}$ to supervise military decisionmaking in the name of the people. ${ }^{57}$ The courts retain the responsibility to see that federal law does not conflict with the requirements of the Constitution; yet this has generally been viewed as a less direct warrant for intervention.

This deference is a particular problem where change requires unmasking military androcentrism. One of the most powerful and self-entrenching features of androcentrism is its tendency to present the partial view of those men in control of an institution as objective reality. Exposing it means noting the entanglement of conclusions driven by technical knowledge and conclusions driven by attitudinal limitations. This task, challenging in any case, will be virtually impossible where the supervising institution displays deference toward military expertise. Determining whether a service chief's claim that gay soldiers will destroy military discipline arises from his special knowledge of what conduces to military discipline, or his unexamined sense that he has experienced discipline only in (what he believed to be) all-heterosexual units, will be impossible if courts believe that military judgments about any matter potentially implicating expertise are entitled to deference.

Courts are also hampered in exposing androcentrism by the kind of reasoning involved in equal protection analysis-the most likely kind of challenge to an exclusionary policy to come before a court. Equal protection analysis employs a categorical framework with three levels of scrutiny, which vary according to the nature of the group affected. ${ }^{58}$ The inquiry is directed first to whether the group has "indicia of suspectness": historical, social, or political characteristics which indicate vulnerability or a legacy of discrimination such as that experienced by, for example, African-Americans. ${ }^{59}$ If such characteristics are present, the policy or statute exposing the group to differentiating treatment is subjected to heightened scrutiny, requiring stronger governmental justification, and a closer relationship between the governmental goal invoked and the discriminating classification employed. This analysis disserves efforts to expose military androcentrism in several ways.

oversight and control of military force by elected representatives and officials which underlies our entire constitutional system .... .

881 F.2d 454, 466 (7th Cir. 1989) (quoting Gilligan v. Morgan, 413 U.S. 1, 10 (1973)).

56. The Constitution makes the president the "Commander-in-Chief of the Army and Navy," U.S. CONST. art. II, § 2, para. 1, and gives Congress the power to "raise and support armies," id. art. I, § 8, para. 12-14.

57. This supervision may be exercised by Congress, through appropriations and other regulations, as well as the power to hold investigatory hearings; civilian supervision may also be exercised by the executive branch, through the president or the Department of Defense. For a fuller discussion of the institutional vehicles for military supervision in the elected branches, see infra at 21-25.

58. See GEOFFrey R. STONE ET AL., CONSTITUTIONAL LAW 532-33, 536-41, 572-81 (2d ed. 1991).

59. See, e.g., Strauder v. West Virginia, 100 U.S. 303 (1879). 
First, equal protection analysis reinforces rather than challenges androcentric logic by focusing on characteristics of groups, rather than on systems of power, and by suggesting that differences are inherent in excluded groups, rather than constructed or highlighted by those in control of institutions. Moreover, because equal protection analysis requires that each group alleging discrimination be scrutinized independently, such analysis may inhibit the kind of juxtaposition of different military policies that would help to expose the systematic character of gender oppression. For example, while the (straight) women's combat exclusion and the gay and lesbian exclusion might both reflect a straight, androcentric attitude toward what conduces to discipline and reinforce traditional notions of masculinity, the two exclusion policies affect distinct (albeit overlapping) groups, and would be analyzed separately, according to the circumstances of each group. ${ }^{60}$

Finally, by treating groups in categorical fashion, equal protection inhibits characterizations that illuminate the multiplicity of excluded groups. Beyond replicating the androcentric assumption that excluded groups should be defined in relation to dominant groups (that is, as similar or as different), categorical equal protection analysis runs all the risks of erasure of the experience of weaker subgroups and privileging of that of more powerful subgroups that are inherent in any unitary characterization of groups. An equal protection challenge to the combat exclusion, which presented women as willing and able to serve, would not be a useful vehicle for amplifying the voices of those who believe, for example, that women should work for peace rather than fight wars, or that the only justification for women's inclusion in combat is to transform the nature of the enterprise. ${ }^{61}$

Despite these drawbacks, however, the courts are not entirely unsuited for playing a role in a challenge to military androcentrism. The political insulation of courts remains a potential asset: they may be hampered by a doctrinal command of deference, but they are not obliged to negotiate directly with those who share current military attitudes, nor are they appointed by anyone who does.

60. In addition, in analyzing the circumstances of different groups, the Supreme Court (and to somewhat lesser extent, other federal courts) have been increasingly reluctant to require strict or even intermediate scrutiny for groups beyond the traditional range including blacks, women and aliens. See generally STONE et al., supra note 58, at 753-57. These factors have meant, in practice, that the effort to draw analogies between (straight) women and other groups entitled to heightened scrutiny, and gays and lesbians, has been complicated and most often unsuccessful. See, e.g., Ben-Shalom v. Marsh, 881 F.2d 454, 465-66 (7th Cir. 1989); Steffan v. Cheney, 780 F. Supp. 1 (D.D.C. 1991).

61 . Or, to highlight another kind of ambivalence blurred by such unitary categorizations, such a challenge would not be a good vehicle for amplifying the voices of the substantial group of military women who find the combat ban stigmatizing and inhibiting to their careers but do not themselves wish to serve in the combat arms. A study published last year showed that, of 868 Army women surveyed, $54-60 \%$ believed that the combat exclusion hurt their chances of promotion, but $52 \%$ would leave the service if they could be compelled to serve in combat roles, as men are. Approximately three quarters of the women surveyed favored replacing the ban with voluntary combat duty for women. These shadings of opinion might be reflected in elected branch deliberations but are utterly obliterated in an equal protection challenge. See Eric Schmitt, Many Women in Army Favor Ending Combat Ban, N.Y. TiMES, Sept. 11, 1992, at A24. 
The lack of a legally sanctioned advisory role can function as a benefit as well. Where courts are willing to undertake substantive scrutiny, their lack of institutional acculturation to military arguments and viewpoints may make them less likely to treat such perspectives as monolithic.

Such scrutiny may be rendered more likely by the fact that judicial deference, potentially disabling though it may be, is discretionary in its application. Judicial acquiescence in military expertise has been punctuated by occasional opinions describing deference as little more than complicity in institutionalized prejudice. ${ }^{62}$ More recently, the district court in Meinhold took a step toward rendering such intervention less idiosyncratic. It said that in evaluating military rationales for discrimination against gays and lesbians, "the court cannot merely defer, but must consider the factual basis underlying military judgment." ${ }^{63}$ This approach not only combats reflexive deference but exposes division in military opinion by examining the forces' inevitably diverse informational base.

Perhaps more importantly, federal lawsuits have recently become the site for a highly innovative form of political organizing that may supply the oppositional reasoning and portraiture that the substance of equal protection challenges lacks. Perhaps, as feminist scholar Mary Katzenstein explains, challenges to the gay and lesbian exclusion policy have become the occasion for a new form of political theater, what she describes as an ingeniously choreographed "spectacle." ${ }^{64}$ As lawyers file their equal protection challenges in court, their clients take their cases on the road, appearing in public fora, coming out on the national news, and even debating prominent military officials on "Nightline." As many of these individuals are coming out for the first time, not only to a nation of strangers but to family and friends, this public presentation contains a strain of personal revelation that renders it immediate and riveting to thousands of viewers. Yet in a more important sense, the images projected are anything but sensational. The excluded servicemen and women are presented as clean-cut, capable, highly accomplished soldiers-indistinguishable, on the one hand, from the myriad of viewers watching them, but possessing sufficient military expertise, on the other, to go toe-to-toe with the military officials with whom they are frequently paired. The result is a powerful set of images of gays and lesbians, generated not by those who wish to distance and devalue them, but by group members and their political allies themselves. These images are aimed not at the courts, or even at the political branches, but at the public, which directly or indirectly influences both.

These images present a powerful challenge to the logic and the substance of military androcentrism. They challenge the universality or objectivity of the

62. See Watkins v. United States Army, 847 F.2d 1329, 1349-51 (9th Cir. 1988); Owens v. Brown, 455 F. Supp. 291, 299-303 (D.C.D.C. 1978).

63. Meinhold v. Department of Defense, 808 F. Supp. 1455, 1458 (C.D. Cal. 1993).

64. Mary Katzenstein, The Spectacle as Political Resistance: Feminist and Gay/Lesbian Politics in the Military, 11 MINERVA 1 (1993). See also William Rubinstein, Challenging the Military's Antilesbian and Antigay Policy, 1 LAW \& SEXUALITY 239, 261-65 (1991) (review of Allen Berube, Coming OUT UNDER FIRE). 
official military view-both of gays and lesbians and of appropriate military policy. They challenge the ostensible need for a ban on gays and lesbians, from the perspective not of an outsider but of one who fully understands the requirements of the military task. When discharged Naval Academy midshipman Joseph Steffan states on "20/20" that "I've been showering with men since I was playing basketball in elementary school. It's something I can deal with . ..,"65 viewers realize - at the least - that military officials' monumental concern with heterosexual "privacy" is only one vantage point on the subject. Moreover, the monolithic military image of the "overt homosexual" is undermined by the image of these recognizable men and women who are characterized not by a predatory lust for heterosexual soldiers but by a commitment to military institutions and a desire to serve. At the level of logic, these images make visible the partiality of dominant views, and confront the dominant practice of constructing gays and lesbians in relation to straight men, rather than as subjects in their own right. These gay and lesbian soldiers, though they have been excluded from their chosen vocation, are subjects in control of their own self-presentation, a revelation that calls the dominant androcentric patterns into question.

These oppositional presentations are not without dangers. In some cases, they seem to perpetuate the image of the "good soldier." Not only are these individuals almost uniformly standouts in their military fields, but they project little sexuality whatsoever; some, like Joseph Steffan, express "disgust" at having to "wear their sexuality on their sleeves." Their presentation is far from the more complex self-revelation one finds in a collection like My Country, My Right to Serve, where gay soldiers tell of entertaining the troops in drag, or initiating sexual encounters with other military men. ${ }^{66}$ Yet the "good soldier," selfpresented on "20/20" or "Nightline" may offer several advantages over the "good soldier" invoked in equal protection challenges or in testimony by advocacy groups. Even where the image presented has little complexity, an image presented simultaneously on hundreds of thousands of television sets across the nation has some hope of competing with the images constructed and disseminated by military leaders. More frequently, the images are more complex and challenging than the foregoing reservation suggests. The "good soldier" who engages in public debate with the military brass, and who can speak to the challenge of showering with other men, is a "good soldier" with a difference. The incongruity or apparent contradiction among the different features of this image helps trigger the recharacterization that nondominant groups seek.

\section{B. Enter the Electoral Branches}

The electoral branches have their own advantages and drawbacks in challenging the androcentrism of military institutions. As a formal matter, they lack the tradition of institutional deference that has frequently paralyzed the

65. 20/20 (ABC television broadcast, Mar. 29, 1991).

66. HuMPHREY, supra note 50 , at 252-54. 
judiciary in addressing discrimination by the military. The president is the Commander in Chief of the Armed Forces-a position that Truman exploited as he desegregated the armed forces by executive order, and on which Clinton hoped to capitalize in his early weeks in office. Congress and the Department of Defense provide civilian supervision to the military services, carrying out a constitutional responsibility not only to assist them but to keep them accountable to the people. This position has given elected branch officials the authority to challenge military judgments; it has enabled them to develop the expertise that has made them feel comfortable in so doing. This authority and expertise can fuel a kind of independent judgment that is capable of separating the opinions of military leaders from "the best defense" of the nation.

In addition, the review of military policy by the elected branches may be conducted through a range of different bodies. Military policy may be altered through the imposition of an executive order. Congress may hold hearings in connection with the passage of legislation, such as the 1974 hearings on legislation which permitted women to enter the service academies, ${ }^{67}$ or in connection with appropriations, such as those sought by President Carter for registration for the draft. ${ }^{68}$ The Department of Defense may issue directives to the services, as when the Assistant Secretary for Manpower and Reserve Affairs instructed the services to eliminate unnecessary regulatory distinctions between men and women, and recommend legislation to correct inequities. ${ }^{69}$ Advisory Committees, such as the Defense Advisory Committee on Women in the Services ("DACOWITS"), ${ }^{70}$ can also be established by or within the executive branch.

The varying backgrounds and constituencies of different elected branch groups tend to enhance the chances of reform-oriented action. ${ }^{71}$ More importantly, the flexible investigatory format of many of these bodies means that

67. Hearings were held in the House Armed Services Committee on the legislation, which was ultimately attached as an amendment to a defense appropriations bill. See HoLM, supra note 34, at 307 10.

68. Hearings were held in 1980 , by subcommittees of both the House and the Senate Armed Services Committees. The Carter Administration's proposal to register women would also have required an amendment to the Military Selective Service Act. See id. at 357-60.

69. See id. at 265 (describing letter to services from Assistant Secretary of Defense for Manpower and Reserve Affairs Roger T. Kelley).

70. DACOWITS was established by the Department of Defense in 1951 to help the services recruit more women (during the Korean War) and to provide a "public relations vehicle" for women's programs within the military. DEVILBISS, supra note 3 , at 10 .

71. At the most basic level, the multiplicity of supervisory avenues increases the likelihood of a challenge to discriminatory policies from some quarter. The "witch hunts" conducted by several services to expose and expel alleged lesbians attracted little attention among elected branch supervisory bodies. See Michelle Benecke \& Kirstin Dodge, Military Women in Nontraditional Job Fields: Casualties of the Armed Forces' War on Homosexuals, 13 HARV. WOMEN's L.J. 215 (1990). Yet DACOWITS was persuaded, after complicated discussions with feminist advocates, that the practice implicated the interests of women as a group, whether they were subject to exclusion or not. See DACOWITS, 1988 Spring Conference (April 16-20, 1988). Perhaps more importantly, the overlapping jurisdiction of supervisory bodies means that one body can given impetus to another in demanding reform. House hearings chaired in 1972 by Representative Otis Pike, which were highly critical of the attitudes of the services concerning the utilization of women, strengthened the hand of the Defense Department in demanding an end to discriminatory regulations. See HoLM, supra note 34, at 265. 
a critique of androcentrism can more readily be voiced. Supervisory bodies are not hampered by the judicial constraint to address only those issues brought before them; they may initiate inquiry and determine the scope of their own investigations. Moreover, elected branch intervention need not replicate the errors of androcentric logic under the auspices of categorical equal protection argumentation. Inquiry need not be limited to the characteristics of affected groups, but may extend to the structure and uses of power within the services. ${ }^{72}$ And some supervisory formats, such as congressional hearings, permit comparison of different gender-related policies, as a way of unearthing more systematic problems in military institutions. $^{73}$

Finally, the flexible investigatory formats and the multiplicity of avenues for supervision militates against the unitary characterization of either military viewpoints or affected groups. Legislative hearings provide civilian officials a chance to hear from a range of military leaders, amplifying whatever diversity of views exists and combatting the impression of a monolithic or universal military judgment on the measures that serve the national defense. ${ }^{74}$ Hearings may also produce multiple, dissimilar images of the group in question. In congressional hearings on the admission of women to the service academies, Representatives Stratton and Wilson emphasized the ability of women to perform like men (the latter even suggesting that this would be possible in combat situations), while Representative Abzug argued that women would bring "a new insight and a new direction toward strategy and tactics."75 And the multiplicity increases as one takes in the images projected by different institutions: the view of women as potential combatants projected by DACOWITS is different from the view of

72. The Pike Subcommittee Report, for example, focused not on the characteristics of women but on the attitudes and practices that hindered their effective utilization in the services. See HoLM, supra note 34 , at $249-50$.

73. During House Armed Services Committee hearings on sexual harassment in July 1992, for example, several witnesses, including Admiral Elmo Zumwalt, Jr. USN (Ret.) and Major General Jeanne Holm USAF (Ret.), raised the relation between the combat exclusion and the unequal and sexualized treatment of military women. PANEL ON DEFENSE POLICY AND THE SUBCOMM. ON MILITARY PERSONNEl AND COMPENSATION OF THE House COMM. ON ARMED SERVICES: Women in the Military: Dealing With Sexual Harassment The 103d Cong., 1st Sess. 26 (1993). The Report reflects an approach broadly critical of the androcentrist military bent in that it calls for systematic "cultural change" in the military. Id. at 3.

74. The 1979 House Armed Services Committee hearings on the repeal of $\$ \$ 6015$ and 8549, for example, reflected a variety of views on the merits of statutorily excluding women from assignment to vessels or aircraft that engage in combat missions. See Holm, supra note 34 , at $338-45$. Holm emphasizes that many who testified in favor of repeal of the statutes did not favor the eligibility of women for combat. Some believed that women should be eligible to serve on combat vessels or aircraft during peacetime, or that service chiefs should have discretion to make assignments not permitted under the statutes, id. at 339; others believed that combat exclusion in the Navy and Air Force should be implemented by service policy, as in the Army, id. Some military officers did, however, testify that women should be permitted in combat. Id. at 340-41. The hearings adjourned without decision on repeal; this action had to await the current administration.

75. See 121 CONG. REC. 15455 (1975), reprinted in LouIs Fisher \& NEAL DEVINS, POLITICAL DYNAMICS OF CONSTITUTIONAL LAW 328-29 (1992). Representative McDonald also opposed the amendment permitting admission on the grounds that women's biological differences in relation to childbearing would make them unable to function in the same way as military men. 121 CONG. REC. at $15453-54$. 
women as potential combatants projected by the recent Presidential Advisory Commission. Moreover, the frequent solicitation of testimony by members of affected groups mean that these groups are at least partly responsible for the images presented, a development that contests the dominant groups' construction of the "other" under androcentrism.

Not all elected branch characteristics, however, serve the effort to challenge military androcentrism. As the recent controversy over gay and lesbian exclusion reveals, institutional strengths can become weaknesses given the wrong personnel or combination of circumstances. The political character of these institutions may theoretically be authorizing, but it can also be practically disenabling. President Clinton-long embattled by the military-felt obliged to respond to the firestorm of objections to his proposed order with compromises which left androcentric assumptions intact. Moreover, as Clinton learned when he faced the challenge of Senator Sam Nunn, ${ }^{76}$ the ability of electoral institutions to nudge and check each other can be an impediment as well as a spur to change. The same can be said of congressional supervisory expertise. Through their close working relationship with the military services, congressional committees can be instilled with the same attitudes that circumscribe the "technical expertise" of the military. Nunn's opposition might be explained on the ground that his commitment to the acquisition of military expertise made him unable to see alternatives to the perspectives of ranking military leaders.

In the end, the most productive approach may lie in a combination of judicial and elected branch influences: a strategic interaction between the executive, the Congress, the courts, and the public. ${ }^{77}$ Such collaboration has already been a pattern in gender-related military reform: a change in service policies making separation for pregnancy voluntary rather than mandatory was accomplished through a combination of litigation, general publicity, and intervention by the Department of Defense. ${ }^{78}$ Such a combination may be particularly useful in reform efforts aimed at exposing military androcentrism. Elected branch mechanisms bring the advantages of flexibility and "jurisdictional redundancy"79; they also contest the unanimity and aperspectivity of military judgments, and proliferate a range of nonunitary images of affected groups. But while executive and legislative institutions may be more effective at illuminating the androcentrism implicit in military practices, they may have drawbacks in initiating a process of systematic change. Judicial decisions are better insulated from pressures to compromise; their conclusive interpretation of the highest law of the land may be more effective in instigating reform. They also may command public attention and combat "other-ization" through media "specta-

76. See Wines, supra note 17.

77. For a useful discussion of such combinations or collaborations in producing social change in a variety of areas, see Neal Devins, Judicial Matters, 80 CAL. L. REv. 1027 (1992) (review of Gerald N. Rosenberg, The Hollow Hope: Can Courts Bring About Social Change?).

78. See STIEHM, supra note 5, at 115-19; HOLM, supra note 34, at 291-303.

79. Robert M. Cover, The Uses of Jurisdictional Redundancy: Interest, Ideology and Innovation, 22 WM. \& MARY L. REV. 639 (1981). 
cles" enabling litigants to construct their own self-images. A simultaneous institutional consideration of specific military policies affecting gender might permit one set of institutions to supply the defects of the other.

For example, as the President, the Department of Defense, and the Senate Armed Services Committee began to work with the services on the proposed executive order, they might have been assisted by the declaration of unconstitutionality handed down in Meinhold. Although Meinhold was a lower court opinion, its conclusion that the exclusion policy violates the Fourteenth Amendment could have played a subtle yet important role in the difficult negotiations ahead. It could have strengthened the hand of the President, enabling him to resist compromises that too closely resembled reinstatement of the ban, by asserting the dubious constitutionality of the courses proposed. The positive media images of Keith Meinhold invoked by the case might have helped problematize official perspectives and fuel public pressure on Senate leaders to ease their opposition to the President.

President Clinton made no effort to exploit the opinion in this way; rather, he permitted himself to be pressured into a compromise reviled by many of his erstwhile supporters. Yet gay and lesbian advocates seem better to have understood the benefits of a multi-branch approach. Failing to persuade the President to hold to his initial pledge, they returned to the courts: Keith Meinhold persuaded Judge Hatter to extend his earlier order. By enjoining as unconstitutional a range of potential actions against gay and lesbian soldiers, Judge Hatter may force contending parties back to the bargaining table, and give gay and lesbian advocates an opportunity for a fuller elected-branch hearing.

\section{IV \\ CONCLUSION}

Discrimination against nonconforming groups by an androcentric military is unlikely to be resolved overnight. Partial, gendered norms that measure performance and limit accommodation are strongly entrenched. It is easy, and not always inappropriate, for military officials to invoke their technical understanding of the defense needs of the nation. Yet the political mobilization of straight women, gays, and lesbians, and the distinguished performance of members of these groups in conflicts such as the Gulf War, have brought a range of policies under scrutiny. The goals of combatting the invisible perspectivity of military leaders, and correcting distorted images of excluded groups, may help organize government officials and active citizens in criticizing these policies and demanding their transformation. 
